\title{
THE EFFECT OF INTERNET USE ON POLITICAL PARTICIPATION: COULD THE INTERNET INCREASE POLITICAL PARTICIPATION IN THAILAND?
}

\author{
Sanyarat Meesuwan* \\ College of Politics and Governance, Mahasarakham University, \\ Kantarawichai, Mahasarakham, 44150 Thailand \\ email: sanyarat@msu.ac.th
}

Published online: 15 July 2016

To cite this article: Meesuwan, S. 2016. The effect of Internet use on political participation: Could the Internet increase political participation in Thailand? International Journal of Asia Pacific Studies 12 (2): 57-82, DOI: 10.21315/ijaps2016. 12.2 .3

To link to this article: http://dx.doi.org/10.21315/ijaps2016.12.2.3

\begin{abstract}
The Internet, as part of information and communication technology, provides citizens with access to information, and allows them to interact with others in online communities. It could also increase the users' political potentials by decreasing the costs and resources' restraints. Given these benefits, this research asks whether or not Internet use would increase political participation in Thailand. Using the 2010 Asian Barometer data conducted in Thailand, the relationship between Internet use and political participation was tested. The results indicate that Internet use positively correlated with political participation, after controlling for individual resource measurement, namely demographic characteristics, education attainment, socio-economic status, political efficacy, and organisational skills. The odds of the respondents, who used the Internet to contact news media to solve their problems with government officials or policies, and to get together with others to raise an issue or sign a petition, were greater than those who did not use the Internet. The findings suggest that the Internet had mobilised people to actively engage in political participation. Policy recommendations aiming at promoting Internet use to encourage political participation and to strengthen the Thai democratic system as a whole are listed at the end of the research.
\end{abstract}


Keywords: Political participation, civic engagement, Internet, democracy, democratic development

\section{INTRODUCTION}

An interview given by Chitpas Bhirombhakdi, a Thai political elite and one of the People's Democratic Reform Committee's core leaders, who organised a mass street protest in Bangkok aiming at overthrowing the Yingluck Shinawatra government in 2013, came as a heavy blow to those wanted to see democracy blossomed in Thailand. She claimed that many Thais lack a "true understanding of democracy... very little awareness was made about politics" (Japan Times 16 December 2013). Unfortunately, Chitpas was not alone in believing in such a presumption. It has long been a case for Thai democracy to blame the inadequate understanding of democracy and the lack of political participation from the citizens as one of the main reasons obstructing democratic development in the country (Askew 2008; Ockey 2004; Uwanno and Burns 1998).

Sharing the same negative attitude toward citizen's political participation, those at the top of political power pyramid have repeatedly alleged that Thai people were too poor and ill-educated to engage in politico-governmental activities. The first written constitution of the kingdom, ratified on 10 December 1932, stated that half of the member of parliaments (MPs) would be appointed by the People's Party, the principal political actor dethroning King Prajadhipok and initially installing a democratic regime in the country. The appointed MP's provision would last until at least half of the Thai population completed primary education, or ten years after the constitution had been ratified, whichever came first (Wyatt 2003).

As time progressed, the distrust on citizens' political comprehension hardly changed among the Thai political elites. The 1997 constitution, considered the first people's constitution in Thailand, required all MPs to hold at least a bachelor degree (Ockey 2004). Also, any attempt of the citizens to engage in politics was often dismissed by those in power, citing that it was performed by poor people who knew nothing about democracy (Uwanno and Burns 1998). Obviously, having a certain level of economic status and education attainment had become a stipulation for the Thai citizens, if they wished to take part in political activities.

In this connection, there were a number of works dealing with democratisation theory that lends weight to assertions by political practices 
in Thailand. Many research confirmed that those better off in terms of education and income were more likely to engage in politics (e.g., Hillygus 2005; Schlozman 2002; Nie et al. 1996; Leighley 1995; Verba et al. 1995; Kenny 1992). Milbrath (1965) explained, to join in any political activities, individuals were required to have a certain amount of time, economic resources, knowledge, and skills. As a result, it is more convenient for people with higher socio-economic status to be active in politics.

It might hold true that the socio-economic factors significantly associate with political participation. However, it was disturbing to witness politicians and political elites in Thailand disregarded public opinions and civic engagement, and justified their practice by citing the socio-economic status of the people. In fact, these prolonged exercise and attitude could hinder the democratisation process in Thailand. This research, hereafter, seeks another explanatory factor, Internet use, that might contribute to the increase in political participation.

In Thailand, the Internet was first introduced at the Prince of Songkla University and Asian Institute of Technology in 1987. In 1988, the Prince of Songkla University registered for an Internet address, and received sritrang.psu.th as their online address. It was the first Internet address in Thailand, and "th" officially became Thailand's domain ever since. At the beginning, the public had a limited use of the Internet. Only students and professors in certain universities in Thailand could access the Internet (Thailand's National Electronics and Computer Technology Center 2010).

The Internet for commercial use in Thailand started in 1995 when the Communications Authority of Thailand (CAT), Telephone Organization of Thailand (TOT) and National Science and Technology Development Agency (NSTDA) established the Internet Thailand Cooperation to provide Internet service to the public. Since then, the Internet has been widely used among Thais. In 1995, there were only 45,000 Internet users in Thailand. The number increased to 21,700,000 in 2014 (Thailand's National Statistics Office 2014). In other words, about one in three of Thai population nowadays entered the World Wide Web.

More importantly, since the coup d'état in 2006 and 2013, the Internet has become an important channel of communication used by the general public and those interested in political activities to access information and to express their political opinions. One of the examples proving that the Internet could be used to support political participation and engagement is the chain of events following the 19 September 192006 coup d'état in Thailand. While the "old media" were gagged that day, many Thais used the Internet as a channel to search for the "truth." Minutes after all national and private television channels played only the Thai national anthem, many 
Internet users posted questions on popular Thai-language discussion websites-Rajadumnern room at Pantip.com, and political section at Mthai.com.

At Pantip.com, within an hour, many discussion pages were created in order to inquire about the situation. Many of Pantip's members then discussed the various possible causes of the coup. As time passed, more people posted about the things they saw. Some members claimed they saw tanks in the streets near the Government House. Many even posted pictures of tanks and soldiers. Moreover, some members started translating and posting news about the coup as reported from online foreign media agencies at the Pantip website. A member of the website told a story of soldiers seizing the Shinawatra III Tower where the ITV station was located. Within two hours of the shutdown of TV stations, many members proceeded to discuss whether or not they should support the coup, and who they wanted to be the next Prime Minister. Obviously, activities on this website indicated that the Internet users still had control of their political rights and freedom of expression.

Seeing these active political activities online, this research asked whether or not Internet use affects the political participation among its users. The study proceeded from the hypothesis that the Internet allows its users to acquire political information and to send messages and their opinions on political issues to other groups of people in the society, leading to an increase in political participation - a crucial foundation of all genuine democratic societies.

Two research objectives, then, were developed in response to the research question:

1. To analyse the association between Internet use and political participation in Thailand;

2. To propose some policy recommendations, based on the research's results, aiming at enhancing the level of political participation in Thailand.

It was hoped that the results of the research could portray the role of the Internet in changing society, and to expand democracy in developing countries, particularly Thailand. 


\section{LITERATURE REVIEW}

Apart from the socio-economic factors school which emphasises the role of socio-economic status as key determinants in predicting individuals' political participation, mobilisation theories offer another explanation on what makes citizens engage in politics. The mobilisation theories hypothesised that communication systems and information availability could provide citizens more compelling opportunities to participate in the political process (Polat 2005).

Unlike previous earlier-generation (or "old") media-newspaper, magazines, television and radio - the Internet is a new kind of communication that allows its users a two-way communication, and to form and expand their "social" networks (Kaid 2004). Given these advantages, many scholars anticipated that the Internet would increase political participation among the citizens and contribute to the advance of democracy (e.g., Kang and Gearhart 2010; Kittilson and Dalton 2008; Jensen et al. 2007; Xenos and Moy 2007; Norris 2001). All of these results from the fact that Internet allows its users to connect with other online "netizens" who either have ideas, beliefs or interests that are similar or otherwise. And these connections subsequently grew to become an online network, one that could later transform into a network in the real world (Kobayashi et al. 2006; Shah et al. 2005; Katz et al. 2001; Wellman et al. 2001).

In Rhiengold's book (2007), it was pointed out that people could form a "virtual community," i.e., "social aggregations that emerge from the Net when enough people carry on discussion long enough, with sufficient human feeling, to form webs of personal relationship in cyberspace." And, this "virtual community" could enhance the level of political participation among its users. Moreover, Jensen et al. (2007) discovered that participants in online engagement come from all social classes and economic status. In short, the Cyberspace transcends one of the major obstacles that prevent people from engaging in the interactions, i.e., socio-economic status, education, and resources.

Overall, scholars cited three impacts the Internet make to foster political participation among its users. Firstly, the Internet with its abundant information could psychologically motivate the users and increase their confidence to the level that they decided to engage in political activities (Stanley and Weare 2004; Barber 2001). Secondly, the Internet could enhance the users' political capacities by decreasing the costs and resources' restraints, and increasing their intra-organisational communicative skillthe most crucial skill to the accumulation and expansion of the "social capital" (Brainard and Siplon 2002; Norris 2002; Dahlberg 2001). 
Significantly, social capital is vital for democracy as it lays groundwork for people to interact and build trust with one another, and forms civic networks (Putnam 2000). Thirdly, the on-liners, via the Internet, would have more opportunities and a new platform to voice their opinions to governments, elected legislators, and administrators. There were a number of studies finding the Internet being used by political activists, politicians, and citizens to accumulate wider collaboration and political engagement (e.g., Milakovich 2010; Garson 2006; West 2002). Figure 1 provides a conceptual framework of how the Internet could increase political participation among its users.

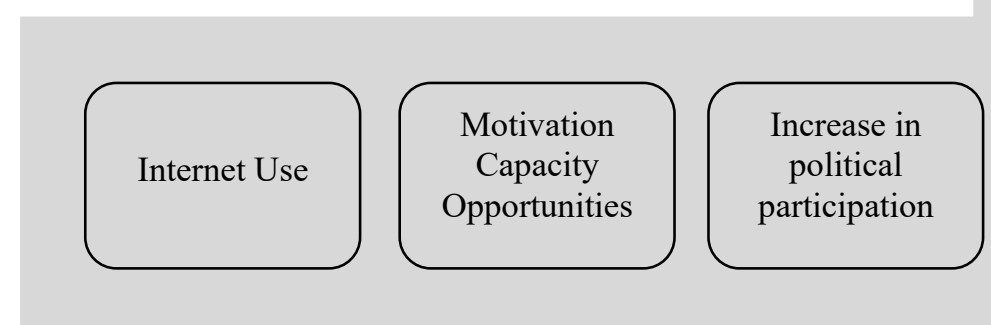

Figure 1: Internet use and its role in increasing civic participation.

Many studies in the past confirmed that the Internet usage increased political participation and efficacy. Additionally, most of these studies applied quantitative research methodology and used statistical analysis as a principal technique. Nisbet and Scheufele (2004) found participating in online political discussion and political campaign was positively correlated to political knowledge. The result of their research is similar to the work of Wellman et al. (2001). In the latter research, the Internet usage was associated with the increase in number of voluntary organisations and political participation. Along the same line, Tolbert and McNeal (2003) studied the Internet users in the United States and found that, after controlling for socio-economic status, those Internet users who seek online political news were more likely to go voting than those who did not. Their result is very similar to Kenski and Stroud's research (2006) on the relationships between seeking online information about the US presidential campaign and the users' political knowledge, efficacy and participation. They found that the correlation between these variables were statistically significant. 
Nonetheless, counter-arguments have been raised against the conclusion on correlations between the Internet and political participation. Scholars from this camp have indicated in essence that the Internet did not generate any new kind of activity or civic skills (Krueger 2002). All activities conducted in the cyberspace are all "old" behaviour. It is, in other words, "old" activities enacted in the "new" medium. Hence, they concluded that the Internet did not produce changes leading toward a democratic development. Although their argument seems sound, they missed the point that the main objective in studying the relationship between the Internet and political participation was not to find "new" behaviour on the Internet. Rather, it was to examine whether or not online interactions among the "WWW" users could increase their political participation and civic attitudes in their real life. Therefore, the discussion on "new" or "old" behaviour has little bearing on this issue.

The studies on political participation and Internet use were relatively new in Thailand. When dealing with political participation, scholars tended to focus more on the demographic and socio-economic factors (e.g., Thananithichot 2012; Glassman 2010; Laothamatas 1996 and 1992). They found that Thai rural people and the poor were more likely to engage more in political processes, but made little influence on policy-making decision. On the contrary, those in urban Thailand, who rarely engaged in political participation, could turn the government decision upside-down. The reason why such dichotomy existed in Thailand, as explained in some research, were that Thai rural people and the poor were politically organised and used as a means to grasp local or national political power by politicians and government authorities. Another explanation was that Thai rural people and the poor did not have enough knowledge on democracy and lacked of civic skills. They mainly participated in politics under the influence of patronclient relationships and vote buying (Askew 2008; Uwanno and Burns 1998; Thanapornphan 1993).

Among the study giving emphasis on the above-mentioned topic, there were few researches examining the correlation between the telecommunication technologies - radio and television-and political participation. Among these very few is Taveesin and Brown's work (2006). By interviewing 500 Thai urban respondents, they confirmed mobilisation theories' thesis that those who gathered information from the television and the Internet, were more likely to engage in political activities.

It is also important to note here that recent studies on the Internet in Thailand tended to centre on the Thai government's effort to crack down online political activities (e.g., Liu 2014; Ramasoota and Panichpapiboon 2014; Navanopparatskul et al. 2013). It was quite clear in the studies that the 
Thai government was interested in the people's activities on the Internet, but not in the direction of promoting their participation in the political process as such. Rather, its intention was to control the people's expression of political opinions.

All in all, this research differs from the previous studies in Thailand in that it dealt with the issue of correlation between Internet use and political participation by using quantitative research technique, and grounded on a dataset collected across the whole country. The result would indicate whether or not the Internet would strengthen citizens' political participation in Thai society.

\section{METHODOLOGY}

\section{Data Sampling}

This research used the third-wave Asian barometer survey as a main data body to analyse the association between political participation and Internet use among Thai people. The Asian Barometer survey in Thailand was conducted by National University of Taiwan, in collaboration with the King Prajadhipok's Institute in 2010.

The population in the survey was the Thai legal voters. It referred to all Thai citizens who were 18 years old and over. The sampling technique employed in this survey was multi-stage systematic random sampling. To select the samples, Thailand was divided into five regions corresponding to the four regions of Thailand. Here, Bangkok was considered as a region in itself. The four regions were the North, the South, the Northeast and the Central Region. From all regions, 40 provinces were randomly selected, followed by the Amphoe (districts) selection. In the third stage, a number of villages in each district were randomly selected in proportion to the population in the selected districts per region. The fourth stage determined the number of people to be surveyed according to the number of selected villages per region. The total number of samples from four regions was 1,212 .

In the case of Bangkok, the survey team used the three-stage random technique. In the first stage, they chose 10 districts out of all 50 districts in Bangkok. Then, in the second stage, they randomly selected 160 subdistricts which comprised of 174,901 Bangkokians. In the last stage, they randomly chose the 300 samples from the selected sub-districts. The total samples from the four regions and Bangkok were 1,512. 


\section{Variables in the Research}

The first objective of this research was to identify the association between Internet use and political participation in Thailand. Hence, the questions in the survey were carefully selected to determine their relationship. The variables and questions used in the research are explained as follows:

\section{Dependent variables}

Political participation is one of the key elements in democracy (Dahl 2000). However, what it is or comprises of is still an on-going debate among scholars in the "democratic theory" domain. It is, therefore, important to clarify what "political participation" refers to in this study. Here we adopted the broad and commonly used definition coined by Verba et al. (1995).

...activity that has the intent or effect of influencing government action - either directly by affecting the making or implementation of public policy or indirectly by influencing the selection of people who make those policies (38).

Accordingly, this study dealt with action made by people inside a society aiming at influencing public policies and decisions of those in power. This definition is broad enough to include all activities that any individual could possibly conduct. At the same time, it excludes those activities that may contain political implications but do not have an intention to change public policies/decisions, such as going to a government agency to register a new member of a household.

The research used four questions-Q35, Q64, Q68 and Q70-from the Asian Barometer survey to represent the political participation of the respondents. Here are the questions:

Q35: Thinking about the national election in 2007, did you try to persuade others to vote for a certain candidate or party?

Q64: In the past three years, have you ever, once, or more than once contacted elected officials or legislative representatives at any level because of personal, family, or neighbourhood problems, or problems with government officials and policies?

Q68: In the past three years, have you ever, once, or more than once contacted news media because of personal, family, or 
neighbourhood problems, or problems with government officials and policies?

Q70: Please tell me whether you, personally, have ever, once, or more than once done any of these things during the past three years. Got together with others to raise an issue or sign a petition?

To answer the Q35, the respondents could choose between yes or no. For the questions, Q64, Q68, and Q70, the respondents had three choices to select from: (1) never; (2) once; or (3) more than once. In this research, the answers from the last three questions were recoded into two groups: yes and no.

\section{Independent variables}

\subsection{Internet use}

The Q45 in the 2010 Asian Barometer's survey asked how often the respondents used the Internet. The respondents had six choices to choose: (1) almost daily; (2) at least once a week; (3) at least once a month; (4) several times a year; (5) hardly ever; or (6) never. The respondents' answers were recoded into two groups-Internet users, and non-Internet users.

\subsection{Individual resource measurement}

Based on Milbrath (1965) and Verba et al. (1995), individual resources referred to demographic characteristics, socio-economic status, education attainment, political efficacy, and organisation skills each individual possesses. In their study, resources were the main factors constraining the individual's political participation. As a result, this study also put all other individual resource measurement variables in the analysis process.

Demographic characteristics: Gender, age and domicile were demographic characteristics in the study. The SE2 variable in the Asian Barometer dataset categorised the respondents into two groups - male and female. The SE3a variable was the respondents' actual age. The researcher recoded this variable into three categories: 18-45 years old; 46-60 years old; and over 60 years old. For domicile, the researcher used the variable named "level3" in the dataset. The Asian Barometer's research team classified the respondents into two groups - those living in urban area, and those in rural area. 
Socio-economic status: The variable SE13 - the respondents' household income, the Asian Barometer's team encoded this variable into five quintiles. However, this study recoded it into three groups. The first and second quintiles were put into low household income category. The middle income households are those in the third and fourth quintiles. And, the fifth quintile belongs to the upper income household group.

Education attainment: The respondents' education attainment were measured in ten levels in the Asian Barometer survey: (1) no formal education; (2) incomplete primary/elementary school; (3) complete primary/elementary; (4) incomplete secondary school/high school (technical/vocational type); (5) complete secondary/high school (technical/vocational type); (6) incomplete secondary school/high school; (7) complete secondary/high school; (8) some university education; (9) complete university education; and (10) post-graduate degree.

From the SE5 variable on education attainment, the researcher recoded it into three groups as follows: (1) had six years of education or lower; (2) had seven to 12 years of education; and (3) had more than 12 years of education.

Political efficacy: The word "political efficacy" referred to how strong the citizens believed in their own ability to influence their government (Niemi et al. 1991). Q134 and Q135 in the survey were employed to measure the respondents' political efficacy. Q134 asked whether or not the respondents agreed with the statement: "Sometimes politics and government seems so complicated that a person like me can't really understand what is going on." Also, Q135 asked the respondents to clarify their agreement with the statement: "People like me don't have any influence over what the government does." The respondents had four choices to choose from: (1) strongly agree; (2) somewhat agree; (3) somewhat disagree; and (4) strongly disagree. The respondents' answers were, again, recoded into two groups: agree and disagree.

Organisation skills: Citizens could learn and develop organisational skills from engaging in voluntary associations or social activities (Putnam 2000; 2002). In the Asian Barometer survey, the respondents were asked whether or not they had ever participated in the following associations: (1) political parties; (2) residential and community associations; (3) religious groups; (4) sports/recreational clubs; (5) culture organisations; (6) charities; (7) public interest groups; (8) labour unions; (9) farmer unions or agricultural associations; (10) professional organisations; (11) business associations; (12) Parent-teacher Associations or PTA; (13) producer cooperatives; (14) consumer cooperatives; (15) alumni associations; (16) 
candidate support organisations; (17) other occupational organisations; and (18) other volunteer organisations.

The answers were recoded into two groups: yes and no.

\section{Hypotheses}

$\mathrm{H}_{1}$ : Internet use positively correlates to political participation

$\mathrm{H}_{2}$ : After controlling for individual resource measurement, Internet use significantly correlates to political participation

\section{Statistics in the Research}

Descriptive analysis, namely frequency and percentage, was employed to provide descriptive characteristics of the dependent and independent variables. Then, the logistic regression analysis was performed to examine the associations between political participation and each independent variable-Internet use, demographic characteristics, socio-economic status, education attainment, political efficacy, and organisational skills. This was followed by hierarchical logistic regression to identify the relationship between political participation and Internet use, after controlling for the independent variables. Only the political activities passing the statistically significant level in the bivariate analysis were included in the hierarchical logistic regression analysis.

\section{RESULTS}

\section{Descriptive Analysis of Variables}

Dependent variables of political participation are described in Table 1. Running a frequency and percentage test on the first dependent variablewhether or not the respondents had persuaded others to vote for a certain candidate or party in the 2007 election, it was found that 1,471 out of 1,512 respondents answered this question. And only 328 respondents or 22.30 percent of all respondents who answered the question had persuaded others to vote for a certain party or candidate in that election. The majority of the respondents (77.70 percent of all respondents) had not performed this political activity in the 2007 election. 
Table 1: Political participation of the sample.

\begin{tabular}{|c|c|c|}
\hline Political participation & Yes & No \\
\hline $\begin{array}{l}\text { Political Participation } 1 \text { : Thinking about the national election } \\
\text { in } 2007 \text {, did you try to persuade others to vote for a certain } \\
\text { candidate or party? }\end{array}$ & $\begin{array}{c}328 \\
(22.30 \%)\end{array}$ & $\begin{array}{c}1,143 \\
(77.70 \%)\end{array}$ \\
\hline $\begin{array}{l}\text { Political Participation 2: In the past three years, have you ever } \\
\text { contacted elected officials or legislative representatives at any } \\
\text { level because of personal, family, or neighbourhood } \\
\text { problems, or problems with government officials and } \\
\text { policies? }\end{array}$ & $\begin{array}{c}348 \\
(23.45 \%)\end{array}$ & $\begin{array}{c}1,136 \\
(76.55 \%)\end{array}$ \\
\hline $\begin{array}{l}\text { Political Participation 3: In the past three years, have you ever } \\
\text { contacted news media because of personal, family, or } \\
\text { neighbourhood problems, or problems with government } \\
\text { officials and policies? }\end{array}$ & $\begin{array}{c}83 \\
(5.65 \%)\end{array}$ & $\begin{array}{c}1,387 \\
(94.35 \%)\end{array}$ \\
\hline $\begin{array}{l}\text { Political Participation } 4 \text { : In the past three years, have you ever } \\
\text { got together with others to raise an issue or sign a petition? }\end{array}$ & $\begin{array}{c}145 \\
(9.74 \%)\end{array}$ & $\begin{array}{c}1,344 \\
(90.26 \%)\end{array}$ \\
\hline
\end{tabular}

In addition, it was revealed that 76.55 percent (1,136 respondents) had never contacted elected officials or legislative representatives at any level because of personal, family, or neighbourhood problems, or problems with government officials or policies in the last three years. On the opposite end, 23.45 percent (348 respondents) had contacted elected officials or legislative representatives. As for the third political participation item, very few of the respondents-5.65 percent-reported they had contacted news media because of personal, family, or neighbourhood problems, or problems with government officials or policies in the last three years. On the other hand, 1,387 respondents (94.35 percent) who answered the question had never engaged in this kind of political activity. Finally, it was found that only 145 of 1,489 respondents (9.74 percent) had got together with others to raise an issue or signed a petition in the last three years. Meanwhile, 90.26 percent (1,344 respondents) had never got together with others to raise an issue or signed a petition in the last three years. Data provided in Table 1 indicates low political participation among the respondents in Thailand.

Independent variables of Internet use and individual resource measurement are explained in Table 2. From the 2010 Asian Barometer survey in Thailand, it was found that 431 out of 1490 respondents, who reported whether or not they had used the Internet (28.93 percent) were Internet users. Also 71.07 percent (1,059 respondents) said they had never used the Internet. 
Table 2: Internet use and individual resource measurement of the sample.

\begin{tabular}{|c|c|c|c|}
\hline & & Frequency & Percent \\
\hline \multirow{2}{*}{ Use of the Internet } & Yes & 431 & 28.93 \\
\hline & No & 1,059 & 71.07 \\
\hline \multirow{2}{*}{ Gender } & Male & 723 & 48.30 \\
\hline & Female & 774 & 51.70 \\
\hline \multirow{3}{*}{ Age (years old) } & $18-45$ & 728 & 48.63 \\
\hline & $46-60$ & 498 & 33.27 \\
\hline & Over 60 & 271 & 18.10 \\
\hline \multirow{2}{*}{ Domicile } & Urban & 373 & 24.67 \\
\hline & Rural & 1,139 & 75.33 \\
\hline \multirow{3}{*}{ Education attainment (years) } & $0-6$ & 879 & 58.25 \\
\hline & $7-12$ & 435 & 28.83 \\
\hline & Over 12 & 195 & 12.92 \\
\hline \multirow{3}{*}{ Family income (quintile) } & $1 \mathrm{st}-2 \mathrm{nd}$ & 892 & 63.17 \\
\hline & $3 r d-4$ th & 436 & 30.88 \\
\hline & 5 th & 84 & 5.95 \\
\hline \multirow{2}{*}{$\begin{array}{l}\text { Sometimes politics and government } \\
\text { seems so complicated that a person like } \\
\text { me cannot really understand what is } \\
\text { going on (Political efficacy 1) }\end{array}$} & Agree & 1,319 & 90.72 \\
\hline & Disagree & 135 & 9.28 \\
\hline \multirow{2}{*}{$\begin{array}{l}\text { People like me do not have any influence } \\
\text { over what the government does (Political } \\
\text { efficacy 2) }\end{array}$} & Agree & 1,005 & 70.63 \\
\hline & Disagree & 418 & 29.37 \\
\hline \multirow{2}{*}{$\begin{array}{l}\text { Had ever participated in social } \\
\text { associations (Organisation skills) }\end{array}$} & Yes & 671 & 51.38 \\
\hline & No & 635 & 48.62 \\
\hline
\end{tabular}

There were more women than men samples, at 51.70 to 48.30 percent. From the survey, 728 respondents or 48.63 percent indicated that their age were between 18 and 45 years old. Additionally, 498 respondents or 33.27 percent were between 46 and 60 years old. The last group, those with age over 60 years old, comprised 18.10 percent of the respondents who reported their age. The Asian Barometer categorised domicile into two groups: rural and urban area. There were 373 respondents who lived in urban area, representing 24.67 percent of total respondents. The remaining 1,139 respondents (75.33 percent) in the survey lived in the rural area of Thailand.

Education attainment is another independent variable in the study. The first group, those with 0-to-6 years of education, comprised of 879 respondents (58.25 percent). In addition, 435 respondents ( 28.83 percent) were those who had 7-to-12 years of education. The minority in the 
education attainment category were those who had over 12 years of education with 195 respondents (12.92 percent). As for family income, there were 892 respondents in the first and second quintile group (63.17 percent of the respondents), who indicated their family income in the survey. The second group-those in the third and fourth quintile family income category-comprised of 436 respondents (30.88 percent). A total of 84 respondents (5.95 percent) were those from the fifth quintile family income category.

The majority of the sample in the survey did not believe they had any influence over the government. Only 135 respondents (9.28 percent) said they disagreed with the statement, "sometimes politics and government seems so complicated that a person like me can't really understand what is going on." Meanwhile, 1,319 respondents (90.72 percent) agreed with the statement. In addition, 418 respondents (29.37 percent) disagreed with the statement, "people like me don't have any influence over what the government does." On the contrary, 1,005 respondents (70.63 percent) agreed with the statement.

The last independent variable in the study is organisation skills, measured by the respondents' participation in any social organisations. It was found that 671 respondents (51.38 percent), have joined social associations. While 635 respondents, (48.62 percent), reported that they had never participated in any social organisations.

\section{Internet Use and Political Participation}

With the first and second hypotheses, this research aims to expand the study conducted by Wellman et al. (2001) that Internet usage had positive effect on political participation. Logistic regression analysis was performed to model the coefficient B of the Internet users to participate in politics. Table 3 presents the logistic regression model of political participation, Internet use, and individual resource measurement, namely: demographic characteristics, socio-economic status, education attainment, political efficacy, and organisational skills.

Of all the independent variables, only domicile $(B=0.915, \mathrm{p}<0.001)$ and political efficacy $1(\mathrm{~B}=-0.591, \mathrm{p}<0.05)$ significantly predicted political participation 1 : persuading others to go for a certain candidate or party (constant $=1.342, \mathrm{R}^{2}=0.048$ ). Political participation 2 , having contacted elected officials or legislative representatives at any level because of personal, family or neighbourhood problems, or problems with government officials and policies, significantly correlated (constant $=2.102, \mathrm{R}^{2}=0.123$ ) with gender $(\mathrm{B}=-0.563, \mathrm{p}<0.001)$, domicile $(\mathrm{B}=0.618, \mathrm{p}<0.01), 7$ to 12 
years of education $(\mathrm{B}=0.496, \mathrm{p}<0.01)$, political efficacy $2 \quad(\mathrm{~B}=0.377$, $\mathrm{p}<0.05)$, and organisational skills $(\mathrm{B}=0.991, \mathrm{p}<0.001)$.

Internet use $(B=1.323, p<0.01)$, gender $(B=0.870, p<0.01)$, and organisational skills $(\mathrm{B}=0.888, \mathrm{p}<0.01)$ significantly predicted political participation 3, having contacted news media because of personal, family, or neighbourhood problems, or problems with government officials and policies (constant $=3.664, \mathrm{R}^{2}=0.117$ ). Whether or not the respondents had got together with others to raise an issue or sign a petition or political participation 4 was the last dependent variable tested in Table 3. It was found that Internet use $(\mathrm{B}=0.868, \mathrm{p}<0.01), 7$ to 12 years of education $(\mathrm{B}=0.572, \mathrm{p}<0.05)$, and organisational skills $(\mathrm{B}=0.920, \mathrm{p}<0.001)$ are significantly associated with political participation 4 (constant -2.974 , $\mathrm{R}^{2}=0.085$ ).

The estimation model predicting differences in political participation between the respondents, who used the Internet and who did not, in Table 3 indicates that there were some differences between these two groups. The significant difference is that the respondents who used the Internet were more actively contacting news media to solve any problems they had with government officials and policies (political participation 3), and to get together with others to raise an issue or sign a petition (political participation 4).

In order to improve the ability to predict the relationship between political participation 3 and 4, and Internet use, the hierarchical logistic regression analysis was employed. This test seems most appropriate, as it could verify the relationship between the dependent and independent variables, when controlling for the other sets of independent variables on the dependent variable. To sum up, Table 4 presents the hierarchical logistic regression test aimed at seeking the relationship between political participation 3 and 4, and Internet use when controlling for other independent variables. 
Table 3: Logistic regression model of political participation, Internet use, and individual resource measurement.

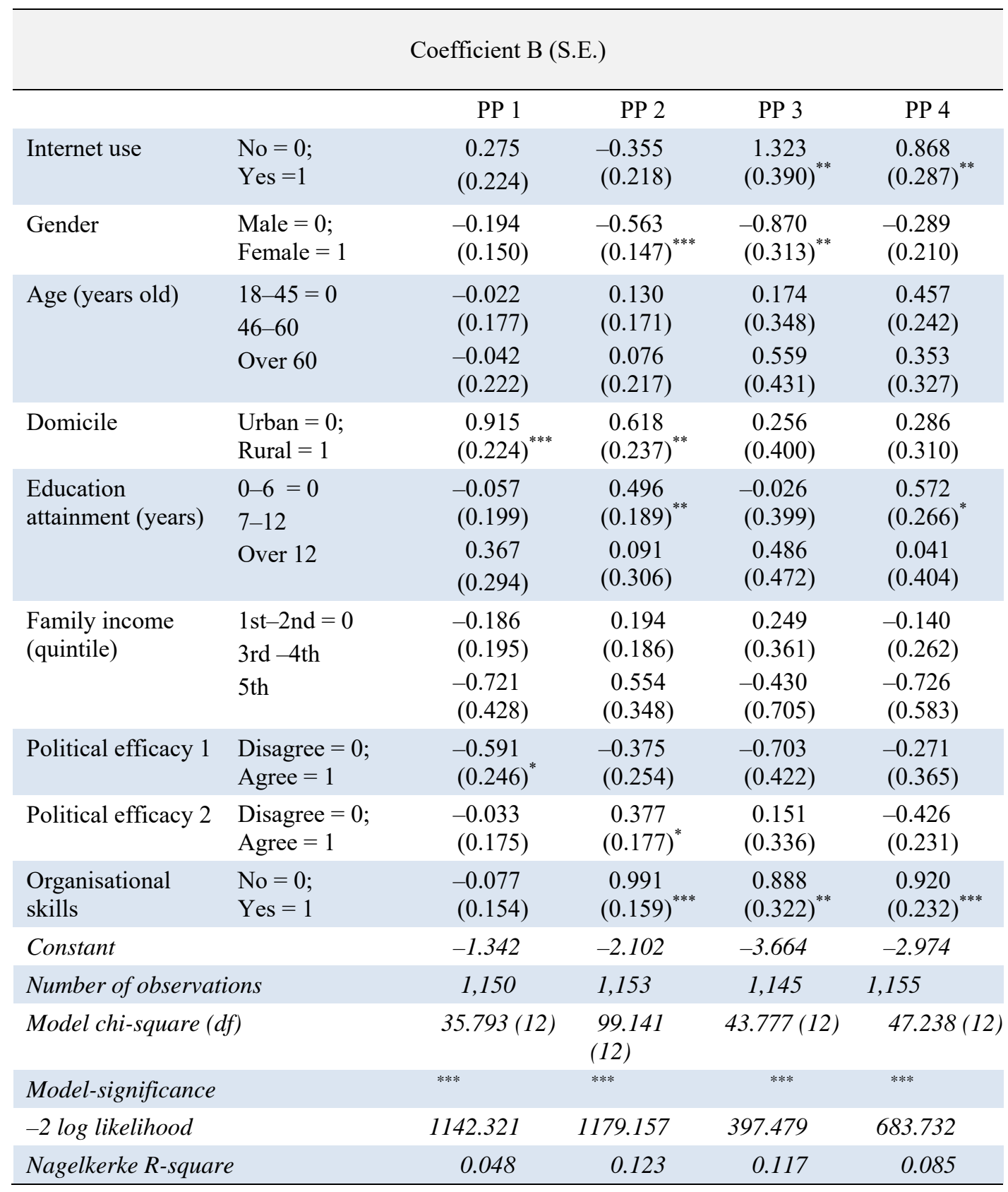

Notes: $\mathrm{PP}=$ Political participation; ${ }^{*} p<.05 ;{ }^{* *} p<.01 ;{ }^{* * *} p<.001$ 
Table 4: Hierarchical logistic regression model of political participation and Internet use after controlling for gender, education attainment, family income, and organisational skills.

\begin{tabular}{|c|c|c|c|c|}
\hline \multicolumn{5}{|c|}{ Coefficient B (S.E.) } \\
\hline & \multicolumn{2}{|c|}{ Political participation 3} & \multicolumn{2}{|c|}{ Political participation 4} \\
\hline & Model I & Model II & Model I & Model II \\
\hline \multicolumn{5}{|l|}{ Control variables } \\
\hline $\begin{array}{l}\text { Gender: } \text { Male }=0 \\
\text { Female }=1\end{array}$ & $\begin{array}{l}-0.919 \\
(0.311)^{* *}\end{array}$ & $\begin{array}{l}-0.870 \\
(0.313)^{* *}\end{array}$ & $\begin{array}{l}-0.327 \\
(0.208)\end{array}$ & $\begin{array}{l}-0.289 \\
(0.210)\end{array}$ \\
\hline 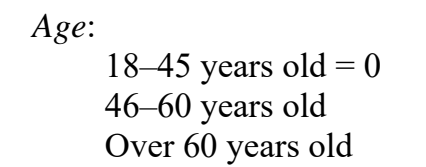 & $\begin{array}{c}-0.016 \\
(0.338) \\
0.299(0.412)\end{array}$ & $\begin{array}{c}0.174 \\
(0.348) \\
0.559 \\
(0.431)\end{array}$ & $\begin{array}{c}0.356 \\
(0.236) \\
0.238 \\
(0.321)\end{array}$ & $\begin{array}{c}0.457 \\
(0.242) \\
0.353 \\
(0.327)\end{array}$ \\
\hline 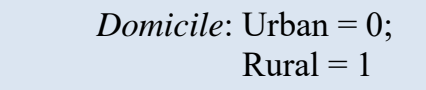 & $\begin{array}{l}-0.157 \\
(0.389)\end{array}$ & $\begin{array}{c}0.256 \\
(0.400)\end{array}$ & $\begin{array}{l}-0.041 \\
(0.292)\end{array}$ & $\begin{array}{c}0.286 \\
(0.310)\end{array}$ \\
\hline $\begin{array}{c}\text { Education attainment: } \\
0-6 \text { years }=0 \\
7-12 \text { years } \\
\text { Over } 12 \text { years }\end{array}$ & $\begin{array}{c}0.229(0.380) \\
0.954 \\
(0.450)^{*}\end{array}$ & $\begin{array}{c}-0.026 \\
(0.399) \\
0.486 \\
(0.472)\end{array}$ & $\begin{array}{l}0.710 \\
(0.258)^{* *} \\
0.381 \\
(0.387)\end{array}$ & $\begin{array}{c}0.572 \\
(0.266)^{*} \\
0.041 \\
(0.404)\end{array}$ \\
\hline $\begin{array}{l}\text { Family income: } \\
\text { 1st-2nd quintile }=0 \\
\text { 3rd-4th quintile } \\
\text { 5th quintile }\end{array}$ & $\begin{array}{c}0.480(0.352) \\
-0.277 \\
(0.712)\end{array}$ & $\begin{array}{l}0.249 \\
(0.361) \\
-0.430 \\
(0.705)\end{array}$ & $\begin{array}{l}0.004 \\
(0.257) \\
-0.611 \\
(0.581)\end{array}$ & $\begin{array}{l}-0.140 \\
(0.262) \\
-0.726 \\
(0.583)\end{array}$ \\
\hline $\begin{array}{l}\text { Political efficacy } 1 \text { : } \\
\quad \text { Disagree }=0 ; \text { Agree }=1\end{array}$ & $\begin{array}{l}-0.667 \\
(0.418)\end{array}$ & $\begin{array}{l}-0.703 \\
(0.422)\end{array}$ & $\begin{array}{l}-0.245 \\
(0.363)\end{array}$ & $\begin{array}{l}-0.271 \\
(0.365)\end{array}$ \\
\hline $\begin{array}{l}\text { Political efficacy 2: } \\
\quad \text { Disagree }=0 ; \text { Agree }=1\end{array}$ & $0.121(0.327)$ & $\begin{array}{c}0.151 \\
(0.336)\end{array}$ & $\begin{array}{l}-0.415 \\
(0.228)\end{array}$ & $\begin{array}{l}-0.426 \\
(0.231)\end{array}$ \\
\hline $\begin{array}{l}\text { Organisational skills: } \\
\qquad \text { No }=0 ; \mathrm{Yes}=1\end{array}$ & $\begin{array}{l}0.933 \\
(0.321)^{* *}\end{array}$ & $\begin{array}{l}0.888 \\
(0.322)^{* *}\end{array}$ & $\begin{array}{l}0.936 \\
(0.231)^{* * *}\end{array}$ & $\begin{array}{l}0.920 \\
(0.232)^{* * *}\end{array}$ \\
\hline \multicolumn{5}{|c|}{ Predictor independent variable } \\
\hline Internet use: No $=0$, Yes $=1$ & - & $\begin{array}{l}1.323 \\
(.390)^{* *}\end{array}$ & - & $\begin{array}{l}0.868 \\
(0.287)^{* *}\end{array}$ \\
\hline Constant & -3.015 & -3.664 & -2.555 & -2.974 \\
\hline Number of observations & 1,145 & 1,145 & 1,155 & 1,155 \\
\hline Model-Chi Square (df) & 32.168 & 43.777 & 38.142 & 47.238 \\
\hline Model-significance & $* *$ & $* *$ & $* * *$ & $* * *$ \\
\hline-2 Log Likelihood & 409.088 & 397.479 & 692.827 & 683.732 \\
\hline Nagelkerke R Square & 0.087 & 0.117 & 0.069 & 0.085 \\
\hline
\end{tabular}

Notes: ${ }^{*} p<.05, * * p<.01, * * * p<.001$ 
The association between political participation 3 and Internet use still existed after controlling for gender, age, domicile, education attainment, family income, political efficacy 1 and 2, and organisational skills (constant $=3.664, \mathrm{~B}=1.323, \mathrm{p}<0.01, \mathrm{R}^{2}=0.117$ ). The number of respondents in the model was 1,145 . The standard errors for the variables included in the analysis were lower than 2.0. It could be concluded that there was no evidence of multicollinearity. In addition, probability of the block chisquare in Model II of political participation 3 was less than the significant level of 0.05 , rejecting that there was any difference between Model I and Model II. In other words, the existence of the hierarchical relationship between the political participation 3 and Internet use was confirmed.

The same conclusion could be applied to the relationship between political participation 4 and Internet use. After controlling for gender, age, domicile, education attainment, family income, political efficacy 1 and 2, and organisational skills, the correlation between political participation 4 and Internet use remained statistically significant (constant $=2.974$, $\mathrm{B}=0.868, \mathrm{p}<0.01, \mathrm{R}^{2}=0.085$ ). No standard errors for the control variables and predictor independent variable, or Internet use, in Model II of political participation 4 was greater than 2.0. In short, multicollinearity among the independent variables was not detected. In the cross-validation analysis, the association between the political participation 4 and Internet use after putting all control variables in the research into the model was statistically significant $(\mathrm{p}<0.001)$.

The results in Table 4 strengthen the model's prediction of positive correlation between the Internet use and the likelihood of the respondents to contact news media to solve any problems they had with government officials and policies. The direction of the relationship between the chances of the respondents to get together with others to raise an issue or sign a petition and Internet use went along the same line, even after controlling for other independent variables - gender, age, domicile, education attainment, family income, political efficacy 1 and 2, and organisational skills. All this might imply that, regardless of their individual resources-demographic characteristics, socio-economic status, education attainment, political efficacy and organisation skills - the Internet users were more likely to engage in political participation. 


\section{DISCUSSION AND POLICY RECOMMENDATIONS}

Reinforced by many studies in the past that socio-economic factorseducation attainment and socio-economic status-were political participation's prerequisites, many Thai political elites believed that only "the have" in the society should engage in politics (Ockey 2004; Uwanno and Burns 1998). As a result, they have attempted to restrain the have-not's political participation.

Seeing this prolonged political attitude, the research aims at finding the correlation between political participation and Internet use in Thailand, in the hope that it could provide another indicator in prediction civic engagement. The study found that, after controlling for individual resources, the Internet users were more likely to contact news media to solve their problems with government official or policies, compared to the non-Internet users. The positive relationship between Internet use and news media's contact might be fostered by the fact that news media in Thailand had provided online platform for the public to voice their concerns or issues with the government officials or policies. Also, the respondents who used the Internet had greater odds to get together with others to raise an issue or sign a petition. After taking into account other independent variables, demographic characteristics, socio-economic status, education attainment, political efficacy and organisation skills, the association remained statistically strong. These results are in line with previous studies (Kenski and Stroud 2006; Nisbet and Scheufele 2004; Tolbert and McNeal 2003; Wellman et al. 2001). More significantly, the findings confirm the mobilisation theory (Polat 2005) that telecommunication technology, namely the Internet, could increase political participation among its users.

The results that indicate a positive correlation between Internet use and political participation could be beneficial for the development of democracy. Potentially, the Internet could be employed as an instrument to facilitate citizens to engage in political activities. In addition, the Internet might bridge the gap between the have and have-not in their civic engagement, as political participation may no longer limit to those who have better access to resources and knowledge as suggested in Milbrath's work (1965).

Followings are the policy recommendations aiming at promoting Internet use to encourage political participation and to strengthen the Thai democratic system as a whole: 
1. In order to employ the Internet as tool to consolidate the country's democracy, the government of Thailand should try to open wider access to and increase Internet use. It is practically impossible for the Internet to help promote political participation in a situation where a large number of people have no access to this communication channel. While the Internet penetration rate in advanced democratic-countries-for instance, the United States, the United Kingdom, Netherlands, Sweden, South Korea and Japan-were well above 80 percent (International Telecommunication Union 2014), only about one third of Thai citizens could access the Internet. The first step, obviously, requires that the Thai government make available this technology to all Thais.

In her study, Norris (2001) pointed out that Internet use required the users to have basic computer literacy and skills. As a result, it is important for the government to support computer education at schools. For those who already left schools, what can be effectively done is to arrange special training courses - for instance, through the Ministry of Education's nonformal education centres, public libraries, or other local governmental agencies, including TV programs aiming at providing the citizens broader educational alternatives.

Apart from providing knowledge of computer and Internet skills, the government should also help supply computers and other necessary equipment so that people can readily access the Internet through service nodes - schools, libraries, and community halls, nationwide-considering that not all groups of people can buy or own a computer, or pay for an Internet connection service fee.

2. Past studies suggested that electronic government (e-government) could help circulate government information to increase citizens' political engagement (e.g., Jaeger 2005; Parent et al. 2005; Chadwick and May 2003). In order to increase channels through which the public can express their political opinions and participate in the country's public policy-making process, as well as exchanging knowledge, opinions and information among themselves, the Thai government should set up online political discussion forums under its or the Parliament's sponsorship. In addition, there should also be a body empowered to oversee these forums, and to digest the general public's opinions and send them to the responsible government agencies or the Parliament. 
3. The Internet became a significant channel many citizens turned to for voicing their political concerns, demands, and opinions. Consequently, legislators, government officials and political elites in Thailand should be aware of the development in this new telecommunication technology. On the issue of providing greater opportunity to the general public to express their political opinions online, the policy-makers are logically required to listen to the public opinions expressed through that channel.

\section{LIMITATION AND FUTURE WORKS}

Studying the Internet's role and impact on societal change and democracy development is a relatively new branch of academic research in Thailand. The Internet itself has not yet spread to all sections of the society. Its impact is at best transitional. As a result, several jigsaw puzzles remain to be identified and understood, many questions need to be answered, on the way to making improvements in our methodology and to building up a more solid body of knowledge that will make the contributions to our society more genuinely meaningful. Longitude study is necessary for following up trends in behavioural changes among the Internet users and non-users in Thailand. The resultant findings might yield a sounder answer to the Internet's impact strength on people's political participation, compared to a study that focuses on a single time interval like this study.

\section{ACKNOWLEDGEMENT}

This work is supported by the Korea Foundation for Advanced Studies' International Scholar Exchange Fellowship for the academic year of 20142015, and Mahasarakham University, Thailand.

\section{NOTES}

Sanyarat Meesuwan is a lecturer in the College of Politics and Governance at Mahasarakham University, Thailand, where she started working in 2006. Taking a leave from the University, she went to further her study at the University of Hawaii at Manoa, where she received her PhD in Political Science in 2013. Her current course load includes teaching comparative politics; research methodology in political science; politics and government of America; and politics and government of East Asia for both undergraduate and graduate programs. In 2014, she was awarded a 
fellowship from the Korea Foundation for Advanced Studies to conduct a research in South Korea for a year. Her current research interests are democratisation and political participation in Thailand, and comparative politics and international relations in the Asia-Pacific region. Her recent research project, funded by the King Prajadhipok's Institute, is on Preah Vihear Temple border dispute between Thailand and Cambodia after the 2013 International Court of Justice ruling.

\section{REFERENCES}

Askew, M. 2008. Performing political identity: The Democrat Party in Southern Thailand. Chiang Mai: Silkworm Books.

Barber, B. 2001. The uncertainty of digital politics: Democracy's uneasy relationship with information technology. Harvard International Review 23 (1): 42-47.

Brainard, L. A. and Siplon, P. D. 2002. Cyberspace challenges to mainstream non-profit health organizations. Administration and Society 34 (2): 141175.

Chadwick, A. and May, C. 2003. Interaction between states and citizens in the age of the Internet: "e-government" in the United States, Britain, and the European Union. Governance: An International Journal of Policy, Administration, and Institutions 16 (2): 271-300.

Dahl, R. 2000. On democracy. Connecticut: Yale University Press.

Dahlberg, L. 2001. The Internet and democratic discourse. Information, Communication, and Society 4: 615-633.

Garson, D. 2006. Public information technology and e-governance: Managing the virtual state. Sudbury: Jones and Bartlett.

Glassman, J. 2010. The provinces elect governments, Bangkok overthrows them: Urbanity, class and post-democracy in Thailand. Urban Study 47 (6): 1301-1323, DOI:10.1177/0042098010362808.

Hillygus, S. D. 2005. The missing link: Exploring the relationship between higher education and political engagement. Political Behavior 27 (1): 25-47.

International Telecommunication Union. 2004. Measuring the information society report 2014. Geneva: International Telecommunication Union.

Jaeger, P. T. 2005. Deliberative democracy and the conceptual foundations of electronic government. Government Information Quarterly 22 (4): 702 719.

Jensen, M. J., Danziger, J. and Venkatesh, A. 2007. Civil society and cyber society: The role of the Internet in community associations and democratic politics. The Information Society 23: 39-50, DOI:10.1080/0197224060105 7528.

Kaid, L. L., ed. 2004. Handbook of political communication research. New Jersey: Taylor \& Francis. 
Kang, S. and Gearhart, S. 2010. E-government and civic engagement: How is citizens' use of city web sites related with civic involvement and political behaviors? Journal of Broadcasting \& Electronic Media 54 (3): 443-462.

Katz, J. et al. 2001. The Internet, 1995-2000: Access, civic involvement, and social interaction American Behavior Scientist 45: 405-419, DOI:10.1177/0002764201045003004.

Kenny, C. B. 1992. Political participation and effects from the social environment. American Journal of Political Science 36 (1): 59-67.

Kenski, K. and Stroud, N. J. 2006. Connections between Internet use and political efficacy, knowledge, and participation. Journal of Broadcasting and Electronics Media 50 (2): 173-192, DOI:10.1207/S15506878jobem500 21.

Kittilson, M. C. and Dalton, R. J. 2008. The Internet and virtual civil society: The new frontier of social capital. California: Center for the Study of Democracy, UC Irvine.

Kobayashi, T. et al. 2006. Social capital online: Collective use of the Internet and reciprocity as lubricants of democracy. Information, Communication and Society 9 (5): 582-611.

Krueger, B. 2002. Assessing the potential of Internet political participation in the United States: A resource approach. American Politics Research 30: 476498.

Laothamatas, A. 1992. Business associations and the new political economy of Thailand: From bureaucratic polity to liberal corporatism. Boulder, CO: Westview Press.

. 1996. A tale of two democracies: Conflicting perceptions of elections and democracy in Thailand. In The politics of elections in Southeast Asia, ed. Taylor, R.H., 201-223. Washington: Cambridge University Press.

Leighley, J. E. 1995. Attitudes, opportunities and incentives: A review essay on political participation. Political Research Quarterly 48 (1): 181-209.

Liu, Y. 2014. Competitive political regime and Internet control: Case studies of Malaysia, Thailand and Indonesia. Cambridge: Cambridge Scholars Publishing.

Milakovich, M. 2010. The Internet and increased citizen participation in government. eJournal of eDemocracy and Open Government 2 (1): 1-9.

Milbrath, L. 1965. Political participation: How and why do people get involved in politics? Chicago: Rand McNally College Publishing Company and University Press of America.

Navanopparatskul, B. et al. 2013. The conceptual framework of intermediary censorship in social media in Thailand. International Journal on Recent and Innovation Trends in Computing and Communication 1 (7): 592-599.

Nie, N. H. et al. 1996. Education and democratic citizenship in America. Chicago: University of Chicago Press. 
Niemi, R. G. et al. 1991. Measuring internal political efficacy in the 1988 national election study. American Political Science Review 85: 1407-1413, DOI:10.2307/1963953.

Nisbet, M. C. and Scheufele, D. A. 2004. Political talk as a catalyst for online citizenship. Journalism and Mass Communication Quarterly 81 (4): 877896.

Norris, P. 2001. Digital divide: Civic engagement, information poverty, and the Internet worldwide. New York: Cambridge University Press. . 2002. Democratic Phoenix: Political activism worldwide. New York: Cambridge University Press.

Ockey, J. 2004. Making democracy: Leadership, class, gender, and political participation in Thailand. Honolulu: University of Hawai'i Press.

Parent, M. et al. 2005. Building citizen trust through e-government. Government Information Quarterly 22 (4): 720-736.

Polat, R. 2005. The Internet and political participation: Exploring the explanatory links. European Journal of Communication 20 (4): 435-459.

Putnam, R. D., ed. 2002. Democracies in flux: The evolution of social capital in contemporary society. New York: Oxford University Press.

. 2000. Bowling alone: The collapse and revival of American community. New York: Simon \& Schuster.

Ramasoota, P. and Panichpapiboon, S. 2014. Online privacy in Thailand: Public and strategic awareness. Journal of Law, Information and Science 23 (1): $1-51$.

Rhiengold, H. 2007. Smart mobs: The next social revolution. Massachusetts: Basic Books.

Schlozman, K. L. 2002. Citizen participation in America: What do we know? Why do we care? In Political science: The state of the discipline, eds. Katznelson, I. and Milner, H. V., 433-461. New York: W.W. Norton.

Shah, D. V. et al. 2005. Information and expression in a digital age: Modeling Internet effect on political participation. Communication Research 32 (5): $531-565$.

Stanley, W. and Weare, C. 2004. The effects of Internet use on political participation: Evidence from an agency online discussion forum. Administration and Society 36: 503-527.

Taveesin, N. and Brown, W. J. 2006. The use of communication technology in Thailand's political process. Asian Journal of Communication 16 (1): 5978.

Thailand's National Electronic and Computer Technology Center. 2010. Statistics of Internet users in Thailand. http://internet.nectec.or.th/ (accessed on 7 April 2015).

Thailand's National Statistics Office. 2014. Botsarup Sumrap Phuboriharn Karnchai Technology Lae Karnsuesarn nai Kruaruean Por Sor 2557 (Summary report for executives on the household use of information and communication technology), National Statistic Office, Bangkok. 
Thai opposition torn between elections and "People's Revolution." 2013. Japan Times, 16 December. http://www.japantimes.co.jp/news/2013/12/16/asiapacific/politics-diplomacy-asia-pacific/thai-opposition-torn-betweenelections-and-peoples-revolution/\#.VO5TvPmUfJI (accessed 3 April 2015).

Thananithichot, S. 2012. Political engagement and participation of Thai citizens: The rural-urban disparity. Contemporary Politics 18 (1): 87-108.

Thanapornphan, R. 1993. Anijalaksana khong kanmueang Thai: Sethasatwikhao waduay kanmueang (Instability of Thai politics: An analysis of political economy). Bangkok: Manager.

Tolbert, C. J. and McNeal, R. S. 2003. Unraveling the effects of the Internet on political participation? Political Research Quarterly 56 (2): 175-185.

Uwanno, B. and Burns, W. D. 1998. The Thai Constitution of 1997: Sources and process. University of British Columbia Law Review 32: 227-248.

Verba, S., Schlozman, K. L. and Brady, H. 1995. Voice and equality: Civic voluntarism in American politics. Cambridge: Harvard University Press.

Wellman, B. et al. 2001. Does the Internet increase, decrease, or supplement social capital? American Behavior Scientist 45 (3): 436-455.

West, D. M. 2002. State and federal e-government in the United States, 2002. Providence: Taubman Center for Public Policy, Brown University.

Wyatt, D. K. 2003. Thailand: A short history. New Haven and London: Yale University Press.

Xenos, M. and Moy, P. 2007. Direct and differential effects of the internet on political and civic engagement. Journal of Communication 57: 704-718. 